\title{
Poor immunological recovery among severely immunosuppressed antiretroviral therapy-naïve Ugandans
}

This article was published in the following Dove Press journal:

HIVIAIDS - Research and Palliative Care

5 December 2013

Number of times this article has been viewed

\author{
Sarah Nanzigu ${ }^{1,2}$ \\ Ronald Kiguba' \\ Joseph Kabanda ${ }^{3}$ \\ Jackson K Mukonzo' \\ Paul Waako' \\ Cissy Kityo ${ }^{4}$ \\ Fred Makumbi ${ }^{3}$
}

'Department of Pharmacology and Therapeutics, Makerere University College of Health Sciences, Kampala Uganda; ${ }^{2}$ Department of Laboratory

Medicine, Karolinska Institute, Stockholm, Sweden; ${ }^{3}$ Institute of Public Health, Makerere University College of Health Sciences, Kampala, Uganda; ${ }^{4}$ Joint Clinic Research Centre, Kampala, Uganda
Correspondence: Sarah Nanzigu Department of Pharmacology and Therapeutics, Makerere University College of Health Sciences, PO Box 7072, Kampala, Uganda Tel +256784843045

Fax +256 4I4 532947

Email snanzigu@chs.mak.ac.ug
Introduction: CD4 T lymphocytes remain the surrogate measure for monitoring HIV progress in resource-limited settings. The absolute CD4 cell counts form the basis for antiretroviral therapy (ART) initiation and monitoring among HIV-infected adults. However, the rate of CD4 cell change differs among patients, and the factors responsible are inadequately documented.

Objective: This study investigated the relationship between HIV severity and ART outcomes among ART-naïve Ugandans, with the primary outcome of complete immunological recovery among patients of different baseline CD4 counts.

Methods: Patients' records at two HIV/ART sites - the Joint Clinic Research Centre (JCRC) in the Kampala region and Mbarara Hospital in Western Uganda - were reviewed. Records of 426 patients $-68.3 \%$ female and 63.2\% from JCRC - who initiated ART between 2002 and 2007 were included. HIV severity was based on baseline CD4 cell counts, with low counts considered as severe immunosuppression, while attaining $418 \mathrm{CD} 4$ cells/ $\mu \mathrm{L}$ signified complete immunological recovery. Incidence rates of complete immunological recovery were calculated for, and compared between baseline CD4 cell categories: $<50$ with $\geq 50,<100$ with $\geq 100,<200$ with $\geq 200$, and $\geq 200$ with $\geq 250$ cells $/ \mu \mathrm{L}$.

Results: The incidence of complete immunological recovery was 158 during 791.9 person-years of observation, and patients with baseline CD4 $\geq 200$ cells $/ \mu \mathrm{L}$ reached the end point of immunological recovery 1.89 times faster than the patients with baseline CD $4<200$ cells $/ \mu \mathrm{L}$. CD4 cell change also differed by time, sex, and site, with a faster increase observed during the first year of treatment. CD4 cell increase was faster among females, and among patients from Mbarara.

Conclusion: Initiating ART at an advanced HIV stage was the main reason for poor immunological recovery among Ugandans. Earlier ART initiation might lead to better immunological responses.

Keywords: baseline CD4 cells, HIV severity, immunological recovery, ART outcome, ART

\section{Introduction}

With access to antiretroviral therapy (ART) expanding in resource-limited settings, assessing factors related to clinical, immunological, and virological outcomes of ART is of great importance. Even though ART is loosely referred to as a lifelong treatment, clinical, immunological and virological outcome measures differ among patients on highly active ART (HAART), with differences reported within and across cohorts. ${ }^{1-6}$ Mortality is among the ART-outcome variables that have been studied extensively, and rates of up to $30 \%$ have been reported during the first year of treatment in some sub-Saharan settings. ${ }^{1-4}$ Mortality among HIV/ART patients has also occurred in other parts of the world, though at rates lower than that reported in the sub-Saharan Africa 
region., 5 Data from Europe and North America showed that 344 out of 12,574 HAART-naïve patients died during a 24,310 person-year follow-up period, ${ }^{5}$ while data from twelve other ART cohorts from North America and Europe showed 1,005 deaths during 61,798 person-years of followup. ${ }^{6}$ It is therefore evident that ART is not a lifelong therapy for all patients.

Other ART-outcome variables, including CD4 recovery, viral suppression, and frequency of AIDS-defining illnesses, have also been shown to differ among HAART patients. ${ }^{5-9}$ Reports from an HIV/ART Swiss cohort showed that over onethird of the patients failed to attain an absolute CD4 count of 500 cells/ $\mu \mathrm{L}$ during a follow-up period of 4 years, ${ }^{7,8}$ and baseline CD4 status was a predictor of immunological recovery.

Baseline CD4 count is one of the factors strongly associated with the observed differences in clinical, virological, and immunological outcomes for patients taking HAART. After stratification of the patients from the above European and North American cohorts according to baseline CD4 counts, analysis showed that baseline CD4 count was strongly associated with progression to AIDS or death, with the highest risk being among patients with baseline CD4 count $<50$ cells/ $\mu \mathrm{L}(0.74)$, and lowest with baseline CD4 $\geq 350$ cells/ $\mu \mathrm{L}(0.14) .{ }^{5}$ Poor survival among patients who initiate ART at low CD4 counts has been observed in other studies. ${ }^{2,5,6,9-14}$ Based on data from some of these studies, immunological and virological recovery was poor among patients who initiated ART at low baseline CD4 counts, with the greatest risk among patients with CD4 count $<50$ cells $/ \mu \mathrm{L}^{5-9}$ Patients in the Swiss cohort who never attained a CD4 count $>500$ cells $/ \mu \mathrm{L}$ (the incomplete immunological responders) had a lower median baseline CD4 T-cell count ( 72 cells $/ \mu \mathrm{L}$ ) compared to that of the complete responders $(225$ cells $/ \mu \mathrm{L})$. The incomplete responders were also reported to have had a significantly smaller annual increase in CD4 counts compared to their counterparts who responded completely. ${ }^{7,8}$ Data presented from studies carried out in France and $\operatorname{Spain}^{15,16}$ showed that up to $14 \%$ of patients who started HAART at low CD4 cell counts never achieved a CD 4 cell count above 200 cells/ $\mu \mathrm{L}$ during a follow up period of 3-4 years. ${ }^{8}$ Data previously reported from the Joint Clinic Research Centre (JCRC) in Uganda showed AIDS-defining conditions and CD4 count $\leq 200$ cells $/ \mu \mathrm{L}$ at baseline to be associated with a longer time to attain immunological recovery. ${ }^{17}$ Although immunologic recovery was defined as gaining $50 \mathrm{CD} 4$ cells $/ \mu \mathrm{L}$, this study highlighted the role of AIDS-defining conditions, and this is very important in settings with limited CD4 cell evaluation.
Reasons for the suboptimal CD4 cell response among HIV patients who start treatment at low CD4 counts are poorly understood, but studies from Uganda demonstrated T-cell exhaustion among patients with suboptimal CD4 recovery after long periods of follow-up with HIV RNA suppression. ${ }^{19,35}$ An earlier study demonstrated that hematopoietic microvascular endothelial cells of HIV-I-infected patients had reduced capacity to respond to cytokine signals that augment blood-cell production. ${ }^{20}$ The study further demonstrated that the percentage of HIV-infected microvascular endothelial cells was ten times higher among patients with CD $4<250$ cells/ $\mu \mathrm{L}$ compared to those with $\mathrm{CD} 4>500$ cells $/ \mu \mathrm{L},{ }^{20}$ indicating that the hematopoietic potential might well be compromised in patients with severe immunosuppression.

Starting ART at low CD4 counts has also been associated with increased toxicity of antiretrovirals (ARVs). Data from the HIV Outpatient Study (HOPS) cohort in the US revealed that initiating therapy at progressively higher CD4 counts cut the risk of three major nucleoside toxicities, namely neuropathy, anemia, and renal insufficiency. ${ }^{21}$ The data further showed that CD 4200 cells $/ \mu \mathrm{L}$ independently increased the risk of peripheral neuropathy 1.54 times, while the risk of anemia was raised 1.58 times and renal insufficiency increased 2.22 times. ${ }^{21}$ Results from 1,286 patients from Kenya, followed for 11.6 months on stavudine, lamivudine, and nevirapine, showed that $\mathrm{CD} 4$ count $<100$ cells $/ \mu \mathrm{L}$ was an independent predictor of peripheral neuropathy. ${ }^{13}$ Data from the ART Cohort Collaboration study in Uganda demonstrated that patients with baseline CD4 $<200$ cells $/ \mu \mathrm{L}$ experienced more toxicities from stavudine, lamivudine, and nevirapine/efavirenz, although these findings did not reach statistical significance. ${ }^{22}$

Other baseline prognostic factors that have been associated with poor ART outcomes among HAART patients include advanced age, viral load $\geq 100,000$ copies $/ \mathrm{mL}$, AIDS diagnosis, duration of HIV infection, and injection drug use. ${ }^{6,7,23}$ Reports relating ART outcome with sex are contradictory, with some studies reporting a better outcome in females, while others have demonstrated males have done better on ART. ART regimen selection also influences HAART outcome, ${ }^{11,12,25}$ while treatment interruptions are associated with poor ART outcomes. ${ }^{7}$ Additional risk baseline factors that have been described in the sub-Saharan region include anemia, low platelet count, and malnutrition. . $2,12,26^{2}$ Johannessen et al reported a 1-year mortality of 55.2\% among Tanzanian patients with severe anemia in comparison to $3.7 \%$ mortality among patients with no anemia. ${ }^{1}$

Uganda follows World Health Organization (WHO) guidelines, and earlier than 2010 and by the time of the 
current study, HAART at the study sites was recommended when absolute CD4 falls below 200 cells/ $\mu \mathrm{L}$, or CD4 200-350 in some patients with WHO clinical stage 3 conditions. ${ }^{31}$ Also, HIV-infected pregnant women with WHO clinical stage 3 disease and CD $<350$ cells $/ \mu \mathrm{L}$ and all patients with WHO clinical stage 4 were recommended to start treatment. ${ }^{31}$ The first line combination consisted of lamivudine/ stavudine + zidovudine + nivirapine/efavirenz. The first ARV program started as early as June 1998 through the initiative of the Joint United Nations Program on HIV/AIDS and the Uganda Ministry of Health HIV Drugs Access Initiative, and data reported from the initial HIV/ART patients showed median baseline CD4 count of 70 (15-183) cells/ $\mu \mathrm{L}$, with poor survival among patients with baseline CD $4<50$ cells/ $\mu \mathrm{L} .{ }^{12}$ Access to treatment remained low due to financial constraints, and patients needed to meet most or all of the costs. This led to a lot of interruptions in treatment and poor laboratory monitoring for patients who started treatment before and during the selected research period (2002-07), as already reported by Kabugo et al. ${ }^{32}$ The WHO " 3 by 5" initiative and the Global and Bush funds later brought great improvement both in increasing the number of patients starting ART and in their monitoring.

Low baseline CD4 cell count and perhaps more aggressive HIV have been reported in Africa. ${ }^{1,2,12,26,28}$ Although people living with HIV/AIDS in sub-Saharan Africa tend to start HAART much later compared to other settings, the effects of time-dependent prognostic factors on ART outcomes are more widely investigated in Europe and North America. In Africa, there are limited studies that specifically investigated immunological recovery, while some had varying definitions for complete immunological recovery contrary to studies in Europe and North America, where immunological recovery was consistently defined as attaining $500 \mathrm{CD} 4$ cells $/ \mu \mathrm{L}$. This study aimed at investigating the effect of baseline CD4 cell counts on ART-outcome measures among HIV-infected Ugandans.

\section{Materials and methods}

The overall objective of the study was to investigate a relationship between HIV severity as measured by baseline CD4 count and ART outcomes among ART-naïve Ugandans. The primary objective was to investigate the effect of baseline CD4 count on immunological recovery. Secondary objectives included investigating the effect of baseline CD4 count on occurrence of new clinical events, and studying other factors influencing immunological recovery.

The primary end point was incidence rates of complete immunological recovery among ART-naïve Ugandans of two baseline CD4 cell categories: $<200$ cells $/ \mu \mathrm{L}$ and $\geq 200$ cells $/ \mu \mathrm{L}$. Secondary end points included the following:

1. To compare incidence rates of complete immunological recovery among ART-naïve Ugandans for other baseline CD4 cell categories, including $<50$ and $\geq 50,<100$ and $\geq 100$, and $<250$ and $\geq 250$ cells $/ \mu \mathrm{L}$

2. To study other factors related to immunological recovery among ART-naïve Ugandans

3. To measure the incidence rates of new clinical events among Ugandans initiating ART at different baseline CD4 count levels

This was an observational study where data collected during routine HIV/ART care at selected sites were analyzed.

The study was carried out at two HIV clinics that had provided ARVs for at least 5 years prior to the onset of the study: the JCRC in the Central region and the HIV center at Mbarara Hospital in the Western region. The JCRC is a private HIV/ART centre that had been providing ARVs for at least 10 years by the time of the study. The HIV center at Mbarara Regional Referral Hospital, which is run by Uganda's Ministry of Health in partnership with the JCRC and Makerere-Mbarara Joint University program, had been providing ART for at least 5 years. Both sites follow the national guidelines and protocol for ART initiation and HIV/ART management, including CD4 T-cell enumeration.

\section{Data collection}

Records belonging to HIV-seropositive Ugandans who initiated treatment between January 2002 and June 2007 were reviewed from Mbarara Hospital in Western Uganda, and the JCRC in Central Uganda. Records were excluded if they lacked baseline CD4 counts, were ART-experienced by the time of the patient's referral to the study site, were reported as having inadequate adherence, or had one CD4 data point in a year. Data collected included clinical events, CD4 counts, and hematology readings, and these were recorded from time of ART initiation until the visit prior to data collection. Data on viral load and adverse drug reactions were too scanty for meaningful analysis, while mortality data were reported to have been lost following a fire accident.

\section{Data management}

Data were double-entered using Epi Info software (Centers for Disease Control and Prevention, Atlanta, GA, USA) and checked for completeness and accuracy prior to export to analysis. A total of 50 records (42 from the JCRC and 18 
from Mbarara) had incomplete identifiers, and were hence not included into the analysis.

\section{Ethical approval}

This study was approved by the ethics committee at Makerere University Faculty of Medicine, the National Council of Science and Technology, and the institutional review boards at the study sites.

\section{Data analysis CD4 recovery over time}

With Stata software (StataCorp, College Station, TX, USA), the average increase in absolute CD4 cell counts during the first 6 months, and then during 1, 2, 3, 4, and 5 years were calculated for patients belonging to baseline CD4 categories $<200$ and $\geq 200$ cells $/ \mu \mathrm{L}$. We observed some inconsistencies in the timing of immunological evaluation, with some data not collected at the expected 6-month time points. In order to get an all-inclusive analysis, we opted to assess absolute CD4 cell increase for the period 0-6 months and then during 1,2,3,4, and 5 years instead of assessing at the end of each 6-month period. The latter option was leading to significant loss of data. We also modeled this data to see the predicted average increase in absolute CD4 cell counts over time for the study population, while considering their immunological status at the time of treatment initiation. A random-coefficient model based on fractional polynomials with correlated random effects was employed. The best-fit model was of second-degree fractional polynomial functions of time adjusted by CD4 T cells at baseline (only two baseline CD4 categories were considered $-<200$ and $\geq 200-$ for this model). Normality of the CD4 T-lymphocyte values was achieved by $\log _{10}$ transformation of data. Of factors that were considered for the model, sex and site were shown to influence the rate of CD4 cell recovery, while age and ART regimen showed no significant effect. In the final model, therefore, the average increase in absolute CD4 cell counts over time was modeled for the patients of the baseline CD4 cell category $(<200$ and $\geq 200$ cells $/ \mu \mathrm{L})$, taking sex and site as covariates.

\section{Analysis for complete immunological recovery}

Although several studies in Europe and North America considered immunological recovery at $500 \mathrm{CD} 4$ cells $/ \mu \mathrm{L}$, we considered a value of $418 \mathrm{CD} 4$ cells/ $\mu \mathrm{L}$, based on a previous study that documented a CD4 reference range of $418-2,105$ cells $/ \mu \mathrm{L}$ for the study population. ${ }^{34}$ Using Stata software, the incidence rates of reaching 418 CD4 cells during 1,000 personal years of follow-up on ART were calculated for the study population and also compared between patients with baseline CD 4 cell counts $<200$ cells/ $\mu \mathrm{L}$ versus patients with baseline CD4 cell counts $\geq 200$ cells $/ \mu \mathrm{L}$. The incidence rates of immunological recovery were calculated by dividing the number of patients with complete immunological recovery (attained $\geq 418$ cells $/ \mu \mathrm{L}$ ) in each baseline CD4 cell category by the total person-years of observation contributed by all of the patients in that category. For each patient, the person-time of observation was calculated from the date of ART initiation until the date with the first CD4 cell measurement $\geq 418$ cells $/ \mu \mathrm{L}$ or the date of last clinical and laboratory evaluation. The incidence rates during 1,000 personal years of follow-up on HAART were then obtained by multiplying the incidence rates obtained for each baseline CD4 cell category by 1,000 personal years of follow-up. The incidence rates of new clinical events were calculated in the same manner. Rate ratios were obtained by dividing the incidence rates of the two baseline CD4 cell categories.

The cutoff level of $200 \mathrm{CD} 4$ cells/ $\mu \mathrm{L}$ was emphasized in the analysis of immunological recovery, based on the fact that it was the WHO reference for initiating HAART at the time of the study. However, following our observation of a baseline interquartile range (IQR) of 41-184 CD4 cells for this studied group, and the implications of very low baseline CD4 cell counts, other comparison cutoff points, including 50 and 100 cells/ $\mu \mathrm{L}$, were employed. An additional CD4 cutoff level of 250 cells/ $\mu \mathrm{L}$ was used during the analysis, since the country was considering treating all HIV patients $<250$ CD4 cells $/ \mu \mathrm{L}$.

\section{Incidence rates of new clinical events}

Using the same software and baseline CD4 cell cutoff points that were employed for complete immunological recovery, the incidences rates of new clinical events during 1,000 personal years of follow-up on HAART were calculated per CD4 cell category. It was difficult in some cases to differentiate AIDSdefining from non-AIDS-defining illness just based on the records. We therefore opted to include all the clinical events that happened during the follow-up period, rather than trying to analyze for new AIDS-defining illnesses.

\section{Results}

All 5,200 patients' files at the selected sites were reviewed to extract 426 HIV-positive subjects who started treatment during the specified period and fulfilled all inclusion/exclusion criteria. The 426 patients had a total of 2,787 visit records, yielding 1,061.1 person years on HAART. However, CD4 
T-lymphocyte evaluation was done at only 1,635 visits, while the remaining visits were clinical visits where CD4 cell evaluation was deemed unnecessary by the clinician or unaffordable by the patients. The majority of the records (63.2\%) were from the JCRC, and $68.3 \%$ of all records belonged to female patients. Median baseline CD4 was 109 cells/ $\mu \mathrm{L}$ (IQR 41-184), with no difference observed in baseline characteristics between the two sites. Baseline characteristics are shown in Table 1.

Ninety-four percent of all patients were initiated on drugs that are recommended for first-line regimens, and the drugs included zidovudine (AZT), stavudine (d4T), efavirenz (Efv), nevirapine (NVP) and lamivudine (3TC). The most common regimen consisted of zidovudine/stavudine/nevirapine, and it was prescribed to $52.4 \%$ of the patients. Although replace-

Table I Baseline characteristics of 426 HIV infected Ugandans who initiated highly active antiretroviral therapy from 2002 to 2007 from HIV clinics at Mbarara Hospital and Joint Clinic Research Centre (JCRC)

\begin{tabular}{|c|c|c|}
\hline Baseline characteristic & $\begin{array}{l}n \\
(\%)\end{array}$ & $\begin{array}{l}\text { Median } \\
\text { (IQR) }\end{array}$ \\
\hline Total patients & $426(100)$ & NA \\
\hline Total visits & $2,787(100)$ & NA \\
\hline Total visits with CD4 data & $\mathrm{I}, 635(100)$ & NA \\
\hline Age (years) & $426(100)$ & $37(32-43)$ \\
\hline Age for female patients (years) & $291(68.3)$ & $35(3 \mid-42)$ \\
\hline Age for male patients (years) & $135(31.7)$ & $38(34.5-45.5)$ \\
\hline Age for JCRC patients (years) & $269(63.2)$ & $37(32-44)$ \\
\hline Age for Mbarara patients (years) & $157(36.8)$ & $36(3 \mid-42)$ \\
\hline Total follow-up period (weeks) & $48,713(100)$ & $100(64-147)$ \\
\hline Total follow-up at JCRC (weeks) & $32,865(67.5)$ & $104(68-168)$ \\
\hline $\begin{array}{l}\text { Total follow-up at Mbarara Hospital } \\
\text { (weeks) }\end{array}$ & $15,846(32.5)$ & $94(6|-| 3 \mid)$ \\
\hline $\begin{array}{l}\text { Baseline CD4 for all patients } \\
\text { (cells } / \mu \mathrm{L} \text { ) }\end{array}$ & $426(100)$ & $109(4 I-184)$ \\
\hline $\begin{array}{l}\text { Baseline CD4 for female patients } \\
\text { (cells } / \mu \mathrm{L} \text { ) }\end{array}$ & $291(68.3)$ & II 8 (44-190) \\
\hline $\begin{array}{l}\text { Baseline CD4 for male patients } \\
\text { (cells } / \mu \mathrm{L} \text { ) }\end{array}$ & $135(3 \mid .7)$ & $139(33-152)$ \\
\hline Baseline CD4 at JCRC (cells $/ \mu \mathrm{L}$ ) & $269(63.2)$ & 107 (39-177) \\
\hline $\begin{array}{l}\text { Baseline CD4 at Mbarara Hospital } \\
\text { (cells/ } \mu \mathrm{L} \text { ) }\end{array}$ & $157(36.8)$ & $109(49-195)$ \\
\hline $\begin{array}{l}\text { Patients initiated on regimens with drugs } \\
\text { recommended for first-line regimens }\end{array}$ & $94 \%$ & \\
\hline $\begin{array}{l}\text { Patients initiated on regimens that } \\
\text { included second-line drugs }\end{array}$ & $6 \%$ & \\
\hline $\begin{array}{l}\text { Patients still on original first-line } \\
\text { regimens by the time of the study }\end{array}$ & $86.4 \%$ & \\
\hline $\begin{array}{l}\text { Patients on first-line regimens by the } \\
\text { time of the study, but original drugs } \\
\text { replaced by other first-line drugs }\end{array}$ & $23.9 \%$ & \\
\hline $\begin{array}{l}\text { Patients switched to second-line } \\
\text { regimens by the time of the study }\end{array}$ & $13.6 \%$ & \\
\hline
\end{tabular}

Abbreviations: NA, not applicable; IQR, interquartile range. ments between first-line drugs occurred during the follow-up period, the majority of the patients were still on first-line regimens by the time of data collection. The second-line ARV drugs that were prescribed to patients included didanosine, tenofovir, emtricitabine and lopinavir/ritonavir (Table 1). Although all patients required treatment according to WHO recommendations, $79.3 \%$ were initiated on ART because their CD4 cell counts were below 200 cells/ $\mu \mathrm{L}$, while the remaining 20.7\% were initiated on treatment because of a World Health Organization (WHO) and Centre for Disease Control (CDC) clinical stage III/IV diagnosis despite their CD4 counts being $\geq 200$ cells $/ \mu \mathrm{L}$.

\section{Results related to CD4 cell increase over time}

Although all the studied patients required ART in accordance with WHO recommendations for resource-limited settings, we observed a difference in the rate and extent of CD4 recovery, depending on whether they started treatment when they were above or below the 200 CD4 cell mark that was recommended then by the WHO. Although the rate of CD4 cell raise was not uniform at any two given periods, a biphasic raise in CD4 $\mathrm{T}$ - lymphocytes was observed for patients in both CD4 cell categories $(<200$ and $\geq 200$ cells $/ \mu L)$. In both cases, the average CD4 cell increase was faster during the first year of treatment. Patients with baseline CD4 counts $<200$ cells/ $\mu \mathrm{L}$ had a much faster average increase of 25 CD4 cells per month during the first 6 months of treatment, but this dropped to an average of seven cells per month in the following 6 months. On the contrary, the average monthly increase for patients with baseline CD 4 counts $\geq 200$ cells $/ \mu \mathrm{L}$ was maintained between nine and 12 cells throughout the first year of treatment. Modeling of the data for the two groups predicted a better overall CD4 cell recovery for patients who started treatment at $\geq 200 \mathrm{CD} 4$ cells $/ \mu \mathrm{L}(P=0.0003)$. These results are demonstrated in Table 2 and Figure 1. There were insignificant CD4 cell increments during the second to fourth years of treatment.

The rate and extent of CD4 recovery also differed by sex and site. Female patients demonstrated a faster CD4 increase and reached higher $\mathrm{CD} 4$ cell levels compared to male patients $(P=0.0005)$, and CD4 increase was faster among patients from Mbarara Hospital compared to the JCRC $(P=0.0107)$. Typically $\log _{10}$-transformed data in a random-coefficient model with fractional polynomials demonstrated a difference between the highest predicted CD4 cell values attainable by female patients who started ART with CD $4>200$ cells $/ \mu \mathrm{L}$ at the Mbarara site and the highest attainable by male patients 
Table 2 CD4 cell increase over time for 426 HIV-infected Ugandans after initiating highly active antiretroviral therapy (HAART)

\begin{tabular}{|c|c|c|c|c|c|c|}
\hline \multirow{2}{*}{$\begin{array}{l}\text { Period on HAART } \\
\text { (weeks) }\end{array}$} & \multicolumn{3}{|c|}{$<200 \mathrm{CD} 4$ cells $/ \mu \mathrm{L}$} & \multicolumn{3}{|c|}{$\geq 200 \mathrm{CD} 4$ cells $/ \mu \mathrm{L}$} \\
\hline & $n$ & Average (SD) & $\begin{array}{l}\text { Average CD4 } \\
\text { increase/month }(\mathrm{Cl})\end{array}$ & $n$ & Average (SD) & $\begin{array}{l}\text { Average CD4 } \\
\text { increase/month }(\mathrm{Cl})\end{array}$ \\
\hline Baseline & 337 & $86(59)$ & NA & 89 & $263(86)$ & NA \\
\hline $\mathrm{I}-26$ & 337 & $236(138)$ & $25( \pm 2.7)$ & 89 & $318(99)$ & $9( \pm 1.9)$ \\
\hline $27-52$ & 324 & $278(I 70)$ & $7( \pm 0.8)$ & 89 & $384(170)$ & II ( $( \pm 2.3)$ \\
\hline $53-104$ & 315 & $308(190)$ & $2.5( \pm 0.1)$ & 89 & $422(188)$ & $3( \pm 0.6)$ \\
\hline $105-156$ & 145 & 335 (177) & $2( \pm 0.3)$ & 46 & $475(2 \mid 3)$ & $4( \pm I .2)$ \\
\hline $157-208$ & 77 & $399(210)$ & $5( \pm I . I)$ & 8 & $393(212)$ & NA \\
\hline $209-260$ & 49 & $398(227)$ & 0 & 3 & $426(27)$ & NA \\
\hline
\end{tabular}

Notes: The CD4 cell increase is compared between patients who started treatment with baseline CD4 cell counts $<200$, and those with baseline CD4 counts $\geq 200$ cells/ $\mu \mathrm{L}$. Period on HAART is presented in weeks. Patients who started treatment with baseline CD4 cell counts $<200$ had an initial rapid increase in CD4 cell counts, but the rate reduced greatly after 6 months on treatment, while patients who started treatment at CD4 cell counts $\geq 200$ cells/ $\mu \mathrm{L}$ maintained their rate of CD4 cell increase during the first year of treatment.

Abbreviations: NA, not applicable; SD, standard deviation; $\mathrm{Cl}$, confidence interval.

who initiated treatment below $200 \mathrm{CD} 4$ cells/ $\mu \mathrm{L}$ from the JCRC, as shown in Figure 2.

\section{Effect of baseline CD4 cell count on immunological recovery and clinical events}

Only $37.1 \%$ of the patients attained the target CD4 count of 418 cells $/ \mu \mathrm{L}$. The median baseline CD4 count for the
$62.9 \%$ nonresponders was 86 cells/ $\mu \mathrm{L}$ (IQR 34-155), while the median CD4 count for the complete responders was 142 cells/ $\mu \mathrm{L}$ (IQR 72-212). Analysis of the data to include additional baseline CD4 levels of 50, 100, and 250 cells $/ \mu \mathrm{L}$ showed a positive correlation between baseline CD4 counts and immunological recovery and a negative correlation with new clinical events. Data in Table 3 show that patients with baseline CD4 counts of $\geq 100$ cells/ $\mu \mathrm{L}$ reached the targeted

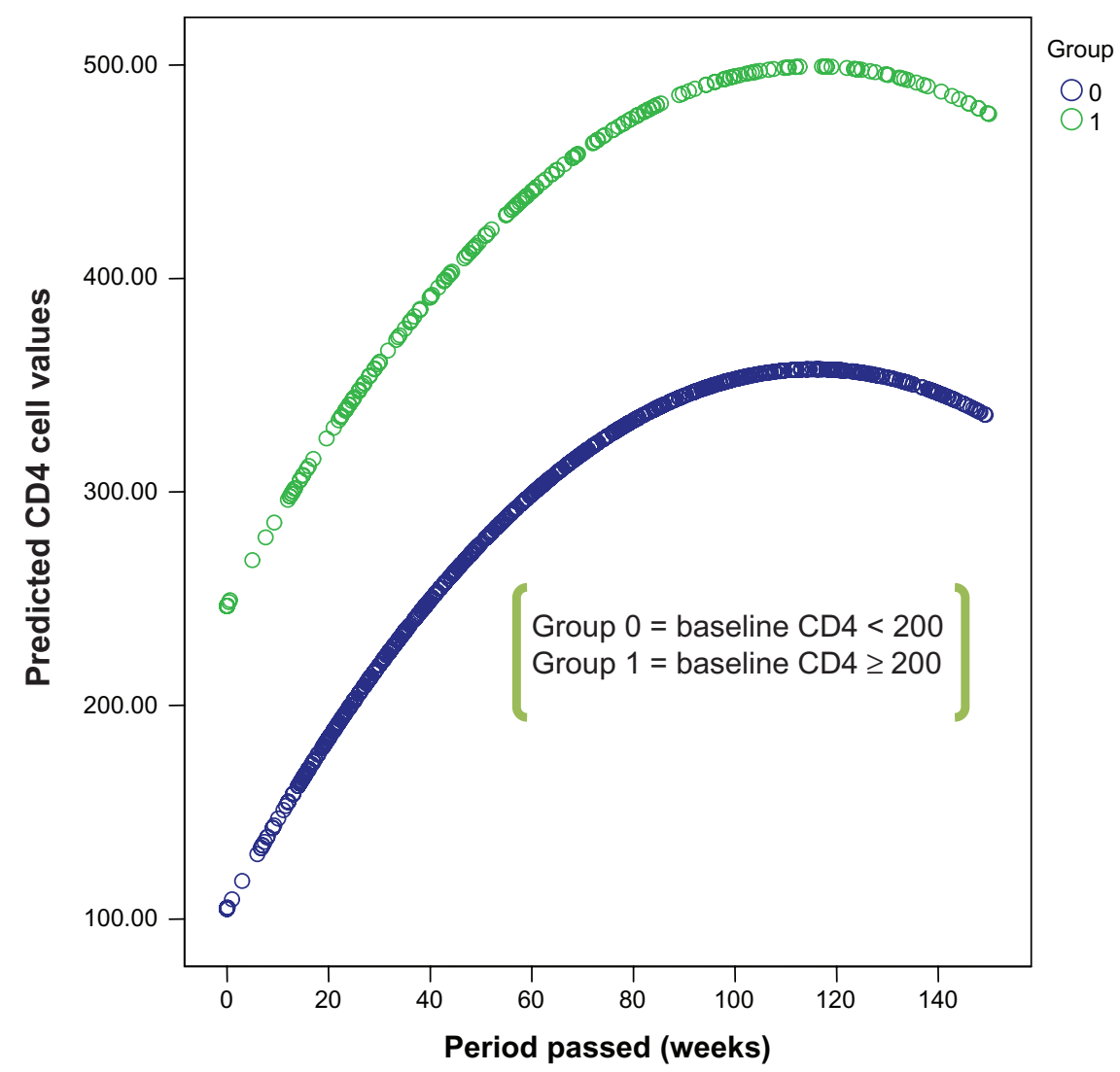

Figure I Predicted change in CD4 cell counts over time for 426 HIV-infected Ugandans initiating highly active antiretroviral therapy at different CD4 categories: group 0 (blue circles) represents patients with baseline CD 4200 cells/ $\mu \mathrm{L}$, while group I (green circles) represents patients with baseline CD4 $\geq 200$ cells/ $\mu \mathrm{L}$. Absolute CD4 cell numbers increased rapidly during the initial year of treatment, and the rate then slowed down during the second year before leveling off. Patients who started treatment with at least $200 \mathrm{CD} 4$ cells/ $\mu \mathrm{L}$ (group I) attained higher CD4 counts than their counterparts (group 0). 


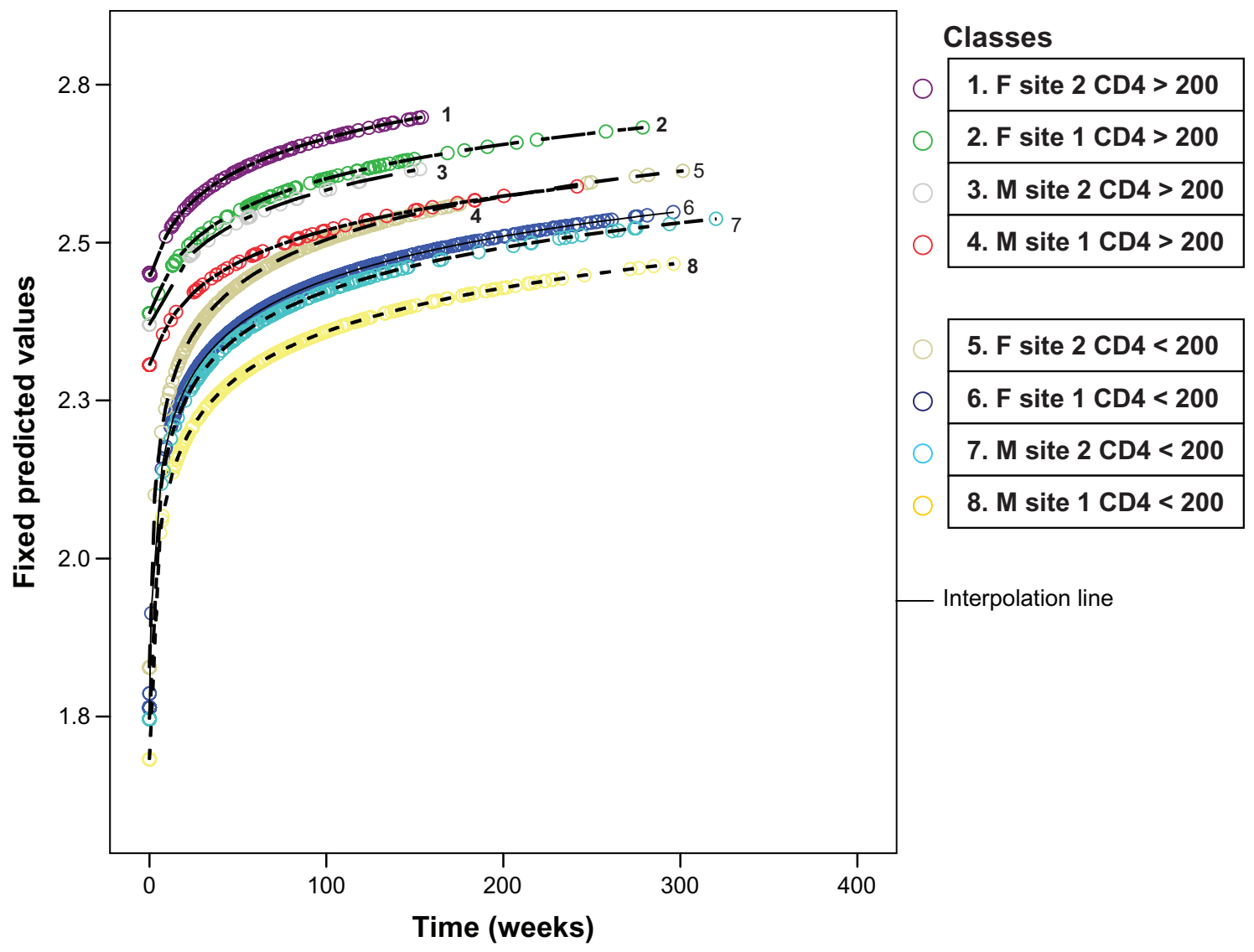

Figure 2 Graph showing differences in sex and site predicted changes in absolute CD4 cell counts for 426 HIV infected Ugandans who initiated highly active antiretroviral therapy at Mbarara Hospital and the Joint Clinic Research Centre (JCRC) in Kampala. Each line represents the average increase in CD4 cell numbers over time, for patients of different sexes at each study site. "F site I" represents female patients at JCRC site, "F site 2" represents female patients at Mbarara Hospital, "M site I" represents male patients at the JCRC, and "M site 2" represents male patients at Mbarara Hospital. The rate of increase over time differed by sex and site. Female patients demonstrated a faster increase and attained higher absolute CD4 cell counts than men, while patients from Mbarara Hospital showed a faster increase in CD4 cells than patients from the JCRC.

418 CD4 count 2.16 times faster compared to patients initiating treatment of $<100 \mathrm{CD} 4$ cells $/ \mu \mathrm{L}$. Likewise, patients with a baseline CD4 count of $\geq 200$ cells $/ \mu \mathrm{L}$ reached 418 cells $/ \mu \mathrm{L} 1.89$ times faster compared to patients initiating treatment $<200 \mathrm{CD} 4$ cells $/ \mu \mathrm{L}$.
Data showed reduced incidence rates of new infections with increasing baseline CD4 count; however, the rate of reduction in clinical events for each increase in baseline CD4 level was very slow, as shown in Table 4 and Figure 3 . The effect of baseline CD4 cell count on different ART outcomes

Table 3 Incidence rates of reaching 4 I8 CD4 cells/ $\mu \mathrm{L}$ among HIV-infected Ugandans who initiated highly active antiretroviral therapy at different CD4 counts

\begin{tabular}{|c|c|c|c|c|c|c|}
\hline $\begin{array}{l}\text { Baseline CD4 } \\
\text { category }\end{array}$ & $n$ & $\begin{array}{l}\text { Incidences of attaining } \\
418 \mathrm{CD} 4 \text { cells } / \mu \mathrm{L}\end{array}$ & $\begin{array}{l}\text { Percentage of incidence } \\
\text { of attaining } 4 \text { I } 8 \text { CD4 } \\
\text { cells/ } \mu \mathrm{L}\end{array}$ & $\begin{array}{l}\text { Total follow-up } \\
\text { period, weeks (years) }\end{array}$ & $\begin{array}{l}\text { Incidence rate/ } \\
\text { I,000 years (range) }\end{array}$ & Rate ratio \\
\hline $0-789$ & 426 & 158 & 37.1 & $4 I,|8|$ (79I.9) & $200(162-238)$ & NA \\
\hline $0-249$ & 396 & 143 & 36.1 & $38,936(748.8)$ & 191 (I52-230) & I.I \\
\hline $0-199$ & 338 & 115 & 34.0 & $34,39 \mid(66 I .4)$ & $174(134-2 \mid 4)$ & \\
\hline$\geq 250$ & 30 & 15 & 50.0 & $2,745(52.8)$ & $284(143-445)$ & 1.49 \\
\hline $0-249$ & 396 & 143 & 36.1 & $38,936(748.8)$ & 191 (I52-230) & \\
\hline$\geq 200$ & 88 & 43 & 48.9 & $6,790(130.6)$ & $329(23 I-427)$ & 1.89 \\
\hline $0-199$ & 338 & 115 & 34.0 & $34,39 \mid$ (66I.4) & $174(|34-2| 4)$ & \\
\hline$\geq 100$ & 231 & 107 & 46.3 & $20,288(390.2)$ & $274(217-332)$ & 2.16 \\
\hline 0-99 & 195 & 51 & 26.1 & $20,893(401.8)$ & $127(80-174)$ & \\
\hline$\geq 50$ & 309 & 122 & 39.5 & 27,966 (537.8) & $227(180-274)$ & 1.60 \\
\hline $0-49$ & 117 & 36 & 30.8 & $|3,2| 7$ (254.2) & I 42 (79-205) & \\
\hline
\end{tabular}

Abbreviation: NA, not applicable. 
Table 4 Incidence rates for new clinical events among HIV-positive Ugandans who initiated highly active antiretroviral therapy at different baseline CD4 cell counts

\begin{tabular}{|c|c|c|c|c|c|}
\hline Baseline CD4 & $\mathbf{n}$ & Incidences & $\begin{array}{l}\text { Total follow-up period, } \\
\text { weeks (years) }\end{array}$ & $\begin{array}{l}\text { Incidence ratel } \\
\text { I,000 years }\end{array}$ & Rate ratio \\
\hline $0-789$ & 426 & 1,007 & $55,179(1061.1)$ & 949 & NA \\
\hline $0-249$ & 396 & 935 & 51,058 (98I.9) & 952 & 0.99 \\
\hline $0-199$ & 338 & 823 & $44,355(853)$ & 965 & \\
\hline$\geq 250$ & 30 & 72 & 4,121 (79.3) & 908 & 0.95 \\
\hline $0-249$ & 396 & 935 & 51,058 (98I.9) & 952 & \\
\hline$\geq 200$ & 88 & 184 & $10,824(208.2)$ & 884 & 0.92 \\
\hline $0-199$ & 338 & 823 & $44,355(853)$ & 965 & \\
\hline$\geq 100$ & 231 & 528 & 29,531 (567.9) & 930 & 0.96 \\
\hline 0-99 & 195 & 479 & $25,648(493.2)$ & 971 & \\
\hline$\geq 50$ & 309 & 694 & $38,836(746.8)$ & 929 & 0.94 \\
\hline $0-49$ & 117 & 311 & $16,343(3 \mid 4.3)$ & 990 & \\
\hline
\end{tabular}

Notes: Rates are compared between patients' categories with baseline CD4 cell counts that are below and above selected values: $<50$ and $\geq 50,<100$ and $\geq 100,<200$ and $\geq 200$, and $<250$ and $\geq 250 \mathrm{CD} 4$ cells/ $\mu \mathrm{L}$. Very minimal reductions in new clinical events were observed among patients with higher baseline CD4 counts. Also, CD4 cell cutoff points used by the country at the time of the study (0-199) and the values that were yet to be adopted by the country (0-249) were compared, and no differences in clinical events were observed.

Abbreviation: NA, not applicable.

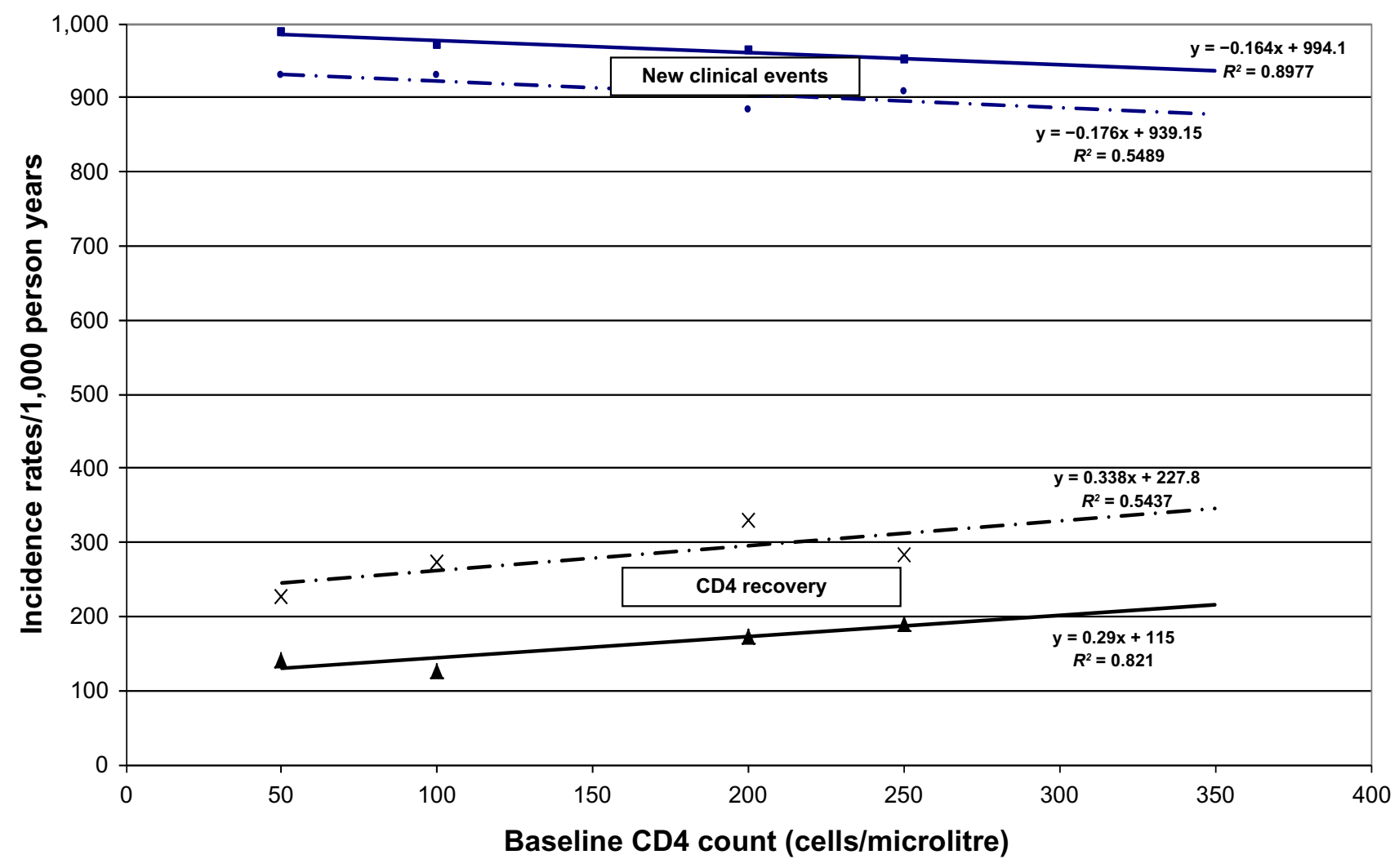

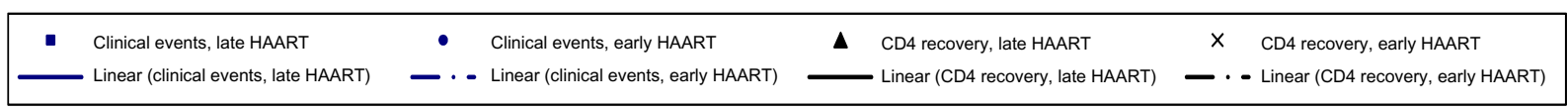

Figure 3 Graph demonstrating the effect of baseline CD4 cell counts on immunological recovery and occurrence of new clinical events for 426 HIV-positive infected Ugandans who initiated highly active antiretroviral therapy (HAART) between 2002 and 2007. The two lower lines represent incidence rates of immunological recovery observed at the different baseline CD4 cell values, while the top two lines represent incidence rates of new clinical events. In both cases, the solid lines represent the rates for patients whose baseline CD4 cell counts had dropped below the corresponding value on the $x$-axis. Broken lines represent the incidence rates for patients whose baseline CD4 cell counts were above the corresponding $x$-axis value. The lower lines show a steady increase in incidence rates of CD4 cell recovery, while the top two lines show a slow reduction in new clinical events with increasing baseline CD4 cell counts. 
is demonstrated in Tables 3 and 4 and Figure 3. Table 3 specifically demonstrates the effect of baseline CD4 T-cell count on immunological recovery, while Table 4 demonstrates the effect on occurrence of new clinical events.

\section{Discussion}

This study related baseline CD4 count as a surrogate for HIV severity and two important ART-outcome measures: immunological recovery and new clinical events. Analysis of clinical data from two HIV centers in Uganda showed that patients who started HAART with higher CD4 counts had better chances of immunological recovery after starting ART, and they had a lower incidence of new clinical events. Overall, $37.1 \%$ of all patients had complete immunological recovery, and the median baseline CD4 count for the complete responders was higher than that of incomplete responders. Differences in rates of increase of CD4 T- lymphocytes were observed as a function of time between the two study sites at the different geographical locations, and female patients attained higher CD4 counts than male patients treated over the same period.

Studies have previously demonstrated poor immunological recovery with low baseline CD4 counts. ${ }^{5,7,14,27-29,33}$ The proportion of patients $(37.1 \%)$ who achieved complete immunological recovery is much lower than that reported in other cohorts, including the $69 \%$ who recovered immunologically in the Swiss cohort. ${ }^{7}$ This could have been due to a low median baseline CD4 count for patients in our cohort compared to the American and European cohorts, again emphasizing the effect of poor immunological recovery with advanced HIV. A biphasic raise in CD4 cells during HAART has been reported from other studies, with the initial phase being faster than the subsequent increments, and the increment being faster among patients starting with low CD4. ${ }^{18,30}$ Though different studies have reported differences in the length of these two phases, Lederman observed an initial raise occurring in 8-12 weeks that is thought to follow redistribution of CD4 cells from lymphoid tissues, while the second phase was characterized by a steady increase in naïve CD4 and CD 8 cells, reflective of enhanced thymic function. ${ }^{18}$ No significant increase in CD4 cell counts was observed after the first year of treatment for the study population, and this may imply poor thymic function following ART initiation in advanced HIV among our study patients.

Our observation of average CD4 cell increase of 150 cells $/ \mu \mathrm{L}$ and 192 cells/ $\mu \mathrm{L}$ at 6 and 12 months, respectively, for patients with baseline CD 4200 cells $/ \mu \mathrm{L}$ is comparable to that reported in other east African countries. An average increase of 169 and 208 cells/ $\mu \mathrm{L}$ was reported for Kenyan patients at 6 and 12 months, respectively, during the study period $2004-06,{ }^{13}$ while a Tanzanian cohort that was treated from 2003 to 2006 had a median increase of 163 cells $/ \mu \mathrm{L}$ after 12 months on ART. ${ }^{1}$ The study populations from the east African reports were similar in baseline CD4 characteristics in having large proportions of patients who initiated treatment at CD4 $<200$ cells $/ \mu \mathrm{L}(77.6 \%$ and $79.1 \%$ for Kenya and Uganda, respectively). These studies also demonstrated the failure of patients with low baseline CD4 to attain full CD4 recovery. Unlike other cohorts that reported significant CD4 cell increase at 3-4 years after starting treatment, ${ }^{15-18}$ our study population showed no significant CD4 cell increases beyond the first year of treatment. This effect may be due to the fact that the majority of these patients (77.6\%) started below 200 cells $/ \mu \mathrm{L}$ and the earlier studies reported poorer response among patients with low CD4 counts, and possibly poor thymic function. Research has also previously described a high proportion of HIV-infected hematopoietic microvascular endothelial cells among patients with advanced HIV, a poor response by these infected cells to stimuli, ${ }^{20}$ and exhaustion of T cells within the bone marrow. ${ }^{19}$

For the benefit of the country, however, this study gives an update on when patients started treatment. Weidle et al reported patients to have initiated treatment with median baseline CD4 cell count of 70 (15-183) between 1998 and $2000 .^{12}$ This study reports a median baseline CD4 of 109 (41-184) for Ugandan HIV-infected patients who were treated from 2002 to 2007 and median CD4 cell count of 131 (57-196) for patients who started treatment in the year 2006 alone. The increase in median baseline CD4 over the years may be attributed to improved access to HIV/ART care and increasing knowledge in HIV care.

Although we found it difficult to analyze for the effect of delayed treatment on new AIDS-defining diagnoses, we report a slow but steady reduction in overall new clinical events at increasing baseline CD4 counts during the observational period, although no statistical differences were detected between the two groups. This could be directly related to the poor CD4-recovery rate, and hence a poorer immunological protection for patients who started treatment late, and the failure to detect statistical differences between the two groups could be due to the weakness of the tool used. Availability and use of AIDS-defining illnesses may have yielded different results. 
Although effect of sex on ART outcomes is poorly documented, Johannessen et al reported an association between male sex and mortality in a univalent analysis for a Tanzanian ${ }^{1}$ cohort who received ART from 2003 to 2006. On the contrary, young male patients from American and European cohorts were reported by Bosch et al to have demonstrated a higher average CD4 cell increase after 144 weeks of ART according to an AIDS Clinical Trials Group study. ${ }^{24}$ There is, however, a huge difference in sex-related demographics, with men representing $82.1 \%$ of Bosch et al's study population, while men constituted $30.3 \%$ and $31.7 \%$ in the Tanzanian and Ugandan studies, respectively. This discrepancy in sex proportions may have contributed to the differences observed in the relationship between sex and ART response.

Although our study sites had no differences in baseline CD4 characteristics and HIV/ART management, patients from Mbarara Hospital demonstrated a faster rate of CD4 cell increase compared to JCRC patients, and it is difficult to explain this observation. The JCRC is more experienced at HIV/ART management given the time period the center has been providing treatment, and we would have expected better outcomes at this site. However, we earlier described how geographic demographics affect CD4 T-lymphocyte cell counts when we reported healthy volunteers from Mbarara having lower mean CD4 cells compared to the Kampala population. ${ }^{34}$ In that previous report, we expressed that individuals with previously high-normal CD4 values may present with falsely high-enough CD4 values in comparison to the national cutoff points for treatment initiation, and we recommended an integration of the knowledge of patients' socioeconomic and health histories in populations with wide CD4 reference ranges. Uganda is a country with a wide CD4 reference range, and patients from Mbarara may have started at an advantage of a better CD4 cell count, given their inherently lower normal CD4 reference than Kampala patients.

Our study had limitations, including the fact that the study had a wide study period (January 2002-June 2007). HIV/ ART care could have improved with time, and this effect may have affected interpretation of our results. Difficulties in getting specific diagnoses from the records limited our analysis to general clinical events, and hence conclusions regarding new AIDS illnesses and adverse drug reactions could not be made. Furthermore, the lack of systematic periodic CD4 cell assessments for some of the studied patients disabled data assessment at specific periods, which is a major flaw in this study.

Nonetheless, these data represent day-to-day HIV/ART management in a resource-limited setting, and they were still considered very representative of what the true ART outcomes are in these settings.

\section{Conclusion and recommendation}

Findings from our study show poor immunological recovery following delayed ART, which could be indicative of possible dysfunction of the microvascular endothelial cells of the bone marrow. We also report differences in immunological recovery with respect to sex and geographical locations, a finding that we related to population variations in CD4 reference values. We recommend early ART initiation to prevent prolonged destruction of the microvascular endothelial cells. Treatment started at the CD4 cell count of $<500$ cells $/ \mu \mathrm{L}$ proposed in the current WHO guidelines, or even earlier, might result in better immunological recovery.

\section{Acknowledgments}

This study was sponsored by the Swedish International Development Cooperation Agency (SIDA) Program as a part of a PhD project under a collaboration between the Karolinska Institute and Makerere University. The authors would like to acknowledge contributions from Professor Lars Gustafsson and Dr Jaran Eriksen of the Karolinska Institute, made while offering guidance to the $\mathrm{PhD}$ student.

\section{Disclosure}

The authors report no conflicts of interest in this work.

\section{References}

1. Johannessen A, Naman E, Ngowi BJ, et al. Predictors of mortality in HIV-infected patients starting antiretroviral therapy in a rural hospital in Tanzania. BMC Infect Dis. 2008;8:52.

2. Zachariah R, Fitzgerald M, Massaquoi M, et al. Risk factors for high early mortality in patients on antiretroviral treatment in a rural district of Malawi. AIDS. 2006;20:2355-2360.

3. Coetzee D, Hildebrand K, Boulle A, et al. Outcomes after two years of providing antiretroviral treatment in Khayelitsha, South Africa. AIDS. 2004; 18:887-895.

4. Etard JF, Ndiaye I, Thierry-Mieg M, et al. Mortality and causes of death in adults receiving highly active antiretroviral therapy in Senegal: a 7-year cohort study. AIDS. 2006;20:1181-1189.

5. Egger M, May M, Chêne G, et al. Prognosis of HIV-1-infected patients starting highly active antiretroviral therapy: a collaborative analysis of prospective studies. Lancet. 2002;360:119-129.

6. May M, Sterne JA, Sabin C, et al. Prognosis of HIV-1-infected patients up to 5 years after initiation of HAART: collaborative analysis of prospective studies. AIDS. 2007;21:1185-1197.

7. Kaufmann G, Perrin L, Opravil M, et al. Effect of 7 years of potent antiretroviral therapy on CD4 T-lymphocyte recovery. In: Program and abstracts of the 12th Conference on Retroviruses and Opportunistic Infections; February 22-25, 2005; Boston, MA. Abstract 612.

8. Cairns G. Long-term CD4 increase on HAART averages 250-350 cells, plateaus after 3-4 years. Presented at: 12th Conference on Retroviruses and Opportunistic Infections; February 22-25, 2005; Boston, MA. 
9. Sterling TR, Chaisson RE, Keruly J, et al. Improved Outcomes with Early Initiation of HAART among HIV-Infected Patients who Achieve Durable Virological Suppression: Longer Follow-up of an Observational Cohort. J Infect. 2003;188:1659-1665.

10. Severe P, Juste MAJ, Ambroise A, et al. Early versus standard antiretroviral therapy for HIV-infected adults in Haiti. N Engl J Med. 2011;363: 257-265.

11. Hogg RS, Heath KV, Yip B, et al. Improved survival among HIVinfected individuals following initiation of antiretroviral therapy. JAMA. 1998;279:450-454

12. Weidle PJ, Mwebaze R, Sozi C, et al. Assessment of a pilot antiretroviral drug therapy programme in Uganda: patients' response, survival, and drug resistance. Lancet. 2002;360:34-40.

13. Hawkins C, Achenbach C, Fryda W, Ngare D, Murphy R. Antiretroviral durability and tolerability in HIV-infected adults living in urban Kenya. J Acquir Immune Defic Syndr. 2007;45:304-310.

14. Manosuthi W, Tansuphaswadikul S, Prasithsirikul W, et al. Incidence and risk factors of major opportunistic infections after initiation of antiretroviral therapy among advanced HIV-infected patients in a resource-limited setting. $J$ Infect. 2007;55:464-469.

15. Le Moing V, Thiebaut R, Raffi F, et al. Long-term evolution of CD4+ cell counts in patients treated with HAART and having a plasma HIV RNA persistently $<500$ copies/mL. In: Program and abstracts of the 12th Conference on Retroviruses and Opportunistic Infections; February 22-25, 2005; Boston, MA. Abstract 609.

16. Esteve A, Jaén A, Casabona J, et al. Long-term immunologic reconstitution (4 years) in Spanish HIV-infected patients on HAART in the PISCIS cohort study. In: Program and abstracts of the 12th Conference on Retroviruses and Opportunistic Infections; February 22-25, 2005; Boston, MA. Abstract 611.

17. Kigozi BK, Sumba S, Mudyope P, et al. The effect of AIDS defining conditions on immunological recovery among patients initiating antiretroviral therapy at Joint Clinical Research Centre, Uganda. AIDS Res Ther. 2009;6:17

18. Lederman MM. Immune restoration and CD4+ T-cell function with antiretroviral therapies. AIDS. 2001;15 Suppl 2:S11-S15.

19. Nakanjako D, Ssewanyana I, Mayanja-Kizza H, et al. High T-cell immune activation and immune exhaustion among individuals with suboptimal CD4 recovery after 4 years of antiretroviral therapy in an African cohort. BMC Infect Dis. 2011;11:43.

20. Moses AV, Williams S, Heneveld ML, et al. Human immunodeficiency virus infection of bone marrow endothelium reduces induction of stromal hematopoietic growth factors. Blood. 1996;87: 919-925.

21. Lichtenstein KA, Armon C, Moorman A, et al. Initiation of antiretroviral therapy at higher CD4+ T cell counts reduces incidence of nucleoside analogue toxicities acutely and risk for later development with continued use of these agents in the HIV outpatient (HOPS) cohort. In: Abstracts of the 4th International AIDS Society Conference on HIV Pathogenesis, Treatment, and Prevention; July 22-25, 2007; Sydney, Australia. Abstract MOPEB016.
22. Forna FM, Liechty CA, Solberg P, et al. Clinical toxicity of highly active antiretroviral therapy in a home-based AIDS care program in rural Uganda. J Acquir Immune Defic Syndr. 2007;44:456-462.

23. Isingo R, Marston M, Ndege M, et al. Survival after HIV infection in the pre-antiretroviral therapy era in a rural Tanzanian cohort. AIDS. 2007;21 Suppl 6:S5-S13.

24. Bosch RJ, Bennett K, Collier AC, Zackin R, Benson CA. Pretreatment factors associated with 3-year (144-week) virologic and immunologic responses to potent antiretroviral therapy. J Acquir Immune Defic Syndr. 2007;44:268-277.

25. Corey DM, Kim HW, Salazar R, et al. Brief report: Effectiveness of combination antiretroviral therapy on survival and opportunistic infections in a developing world setting: an observational cohort study. J Acquir Immune Defic Syndr. 2007;44:451-455.

26. Lawn SD, Myer L, Bekker LG, Wood R. CD4 cell count recovery among HIV-infected patients with very advanced immunodeficiency commencing antiretroviral treatment in sub-Saharan Africa. BMC Infect Dis. 2006;6:59.

27. Lawn SD, Myer L, Orrell C, Bekker LG, Wood R. Early mortality among adults accessing a community-based antiretroviral service in South Africa: implications for programme design. AIDS. 2005;19: 2141-2148.

28. Breton G, Lewden C, Spire B, et al. Characteristics and response to antiretroviral therapy of HIV-1-infected patients born in Africa and living in France. HIV Med. 2007;8:164-170.

29. Severe P, Leger P, Charles M, et al. Antiretroviral therapy in a thousand patients with AIDS in Haiti. N Engl J Med. 2005;353:2325-2334.

30. Lok JJ, Boscha RJ, Bensonb CA, et al. Long-term increase in CD4R T-cell counts during combination antiretroviral therapy for HIV-1 infection. AIDS. 2010;24:1867-1876.

31. World Health Organization. Antiretroviral Therapy for HIV Infections in Adults and Adolescents: Recommendations for a Public Health Approach. Geneva:WHO; 2006. Available from: http:/www.who.int/ hiv/pub/guidelines/artadultguidelines.pdf. Accessed August 28, 2013.

32. Kabugo C, Bahendeka S, Mwebaze R, et al. Long-term experience providing antiretroviral drugs in a fee-for-service HIV clinic in Uganda: evidence of extended virologic and CD4+ cell count responses. J Acquir Immune Defic Syndr. 2005;38:578-583.

33. Mascolini M. Starting ART at higher CD4 count lowers nucleoside toxicity risk. In: Abstracts of the 4th International AIDS Society Conference on HIV Pathogenesis, Treatment, and Prevention; July 22-25, 2007; Sydney, Australia.

34. Nanzigu S, Waako P, Petzold M, et al. CD4-T-lymphocyte reference ranges in Uganda and its influencing factors. Lab Med. 2011;42: 94-101.

35. Baker CA, Emenyonu N, Ssewanyana I, et al. Profile of immunologic recovery in HIV-infected Ugandan adults after antiretroviral therapy. AIDS Res Hum Retroviruses. 2007;23:900-905.
HIV/AIDS - Research and Palliative Care

\section{Publish your work in this journal}

HIV/AIDS - Research and Palliative Care is an international, peerreviewed open-access journal focusing on advances in research in HIV, its clinical progression and management options including antivira treatment, palliative care and public healthcare policies to control viral spread. The journal welcomes original research, basic science,

\section{Dovepress}

clinical \& epidemiological studies, reviews \& evaluations, expert opinion \& commentary, case reports \& extended reports. The manuscript management system is completely online and includes a very quick and fair peer-review system. Visit http://www.dovepress.com/ testimonials.php to read real quotes from published authors. 